\title{
Cryobiology of the freeze-tolerant gall fly Eurosta solidaginis: overwintering energetics and heat shock proteins
}

\author{
Richard E. Lee, Jr ${ }^{1}$, Robyn A. Dommel ${ }^{1}$, Karl H. Joplin ${ }^{2}$, David L. Denlinger ${ }^{2}$ \\ ${ }^{1}$ Department of Zoology, Miami University, Oxford, Ohio 45056, USA \\ ${ }^{2}$ Department of Entomology, The Ohio State University, Columbus, Ohio 43210, USA
}

\begin{abstract}
The goldenrod gall fly Eurosta solidaginis (Diptera: Tephritidae) ranges from the southern U.S. northward into Canada. The larva overwinters within a ball gall on the stem of goldenrod Solidago spp. The galls often extend above the snowpack, exposing the larva to a wide range of environmental extremes in winter. This species has received extensive attention as a freeze-tolerant insect model. A seasonal study of the overwintering bioenergetics of an Ohio, USA, population revealed marked decreases in body weight, lipid and total caloric content in October and November when environmental temperatures were the highest. Overwintering larvae produce heat shock proteins in response to hightemperature exposure. However, unlike other insects E. solidaginis does not appear to synthesize heat shock proteins in response to low-temperature exposure.
\end{abstract}

KEY WORDS: Cold-hardiness - Insect - Low temperature adaptation - Respiration - Stress proteins

\section{INTRODUCTION}

The goldenrod gall fly Eurosta solidaginis (Diptera: Tephritidae) has received extensive study as an insect. model for the study of freeze tolerance (see reviews by Storey \& Storey 1988, Baust \& Nishino 1991). This paper briefly summarizes the overwintering biology and cold-hardiness of this species and provides new information related to its overwintering bioenergetics and its potential for the expression of heat shock (stress) proteins in response to high and low temperatures.

\section{NATURAL HISTORY AND GEOGRAPHIC DISTRIBUTION}

The goldenrod gall fly is distributed extensively in North America, ranging from Florida and Texas, northward to New Brunswick and across Canada to British Columbia (Uhler 1951, Miller 1959, Waring et al. 1990). This species induces the formation of spherical stem galls in various species of goldenrod, Solidago altissima, S. canadensis, S. gigantea and S. ulmifolia (Compositae) (Waring et al. 1990).
Adults of this univoltine species emerge in the spring or early summer, mate and oviposit in the unfolded leaves of the terminal bud of the goldenrod plant (Uhler 1951). Larvae pass through 2 instars during the summer and overwinter within the gall as a third instar. Details of the life history are provided by Uhler (1951, 1961), Miller (1959), and other references cited here

A number of natural enemies attack the overwintering larvae. They are commonly parasitized by Eurytoma obtusiventris and E. gigantea (Hymenoptera: Eurytomidae). Because inquiline larvae of Mordellistina unicolor (Coleoptera: Mordellidae) that burrow into the central chamber of the gall often consume Eurosta solidaginis larvae, they are sometimes referred to as accidental predators (Uhler 1951, Cane \& Kurczewski 1976). Downy woodpeckers Dendrocopus pubescens and black-capped chickadees Parus atricapillus are also common predators of overwintering larvae (Abrahamson et al. 1989). Recent studies have examined aspects of the behavior, ecology and evolutionary relationships between the gall-making E. solidaginis, its host plant, and associated parasites and predators (see references in Abrahamson et al. 1989 and Waring et al. 1990). 


\section{COLD-HARDINESS}

Many of the galls on the senescent goldenrod stems remain above the snowpack, exposing the overwintering larvae to extreme environmental conditions. In western New York, Layne (1991) reported daily temperature fluctuations within the larval chamber of 20 to $30^{\circ} \mathrm{C}$ in September and October. This study demonstrated that the gall provides little or no thermal buffering of changes in ambient temperatures.

During the summer and early autumn Eurosta solidaginis is intolerant of freezing; however, in response to environmental cues, larvae acquire freeze tolerance in mid- to late autumn (Morrissey \& Baust 1976). Larvae survive the freezing of more than $60 \%$ of their body water (Lee \& Lewis 1985).

The supercooling point, sometimes referred to as the temperature of crystallization, is the temperature at which ice nucleation occurs spontaneously within body fluids. For freeze-tolerant larvae the supercooling point is usually in the range of -8 to $-10^{\circ} \mathrm{C}$ (Table 1), although southern populations sometimes have a value of $-14^{\circ} \mathrm{C}$ or lower (Baust \& Lee 1981). In northern populations the lower lethal limit of freeze tolerance extends to $-55^{\circ} \mathrm{C}$ or below, whereas larvae from Texas can survive internal ice formation and cooling to at least $-25^{\circ} \mathrm{C}$ (Baust \& Lee 1981).

During autumn, when the third-instar larvae of Eurosta solidaginis acquire freeze tolerance, their supercooling points increase from summer values below $-12^{\circ} \mathrm{C}$ into the -8 to $-10^{\circ} \mathrm{C}$ range. Recently Layne et al. (1990) demonstrated that the overwintering larvae are susceptible to inoculative freezing early in the autumn when the plant galls still have a relatively high water content. This observation is important because it suggests that under natural conditions the larvae may freeze several weeks earlier than would be predicted on the basis of supercooling points determined on larvae removed from the gall.

Unlike other freeze-tolerant insects, Eurosta solidaginis does not appear to contain ice-nucleating proteins in its hemolymph (Bale et al. 1989a). Within the Malpighian tubules of these overwintering larvae we found large calcium phosphate crystals that had ice nucleating activity as high as $-7.8^{\circ} \mathrm{C}$, a value similar to the whole-body supercooling point of the larvae (Lee et al. 1992). Ice nucleating activity is also present in a number of other crystalline compounds that are found in insects, suggesting that these endogenous crystals represent a new class of heterogeneous ice nucleators capable of regulating supercooling capacity in overwintering insects

In contrast to Eurosta solidaginis, which elevates its supercooling point during its cold-hardening, the other gall inhabitants, the beetle Mordellistina unicolor and the 2 eurytomid wasps, use a different overwintering strategy (Baust et al. 1979). These species enhance their supercooling capacities to -20 to $-30^{\circ} \mathrm{C}$, thereby decreasing the chance that ice nucleation will occur within their tissues.

The overwintering larvae sequentially accumulate a multi-component set of low-molecular-weight cryoprotectants that collectively may reach concentrations greater than $1 \mathrm{M}$ (Morrissey \& Baust 1976). The phenology of the synthesis and accumulation of these compounds is linked to at least 2 environmental cues. In the early autumn desiccation of the plant gall tissue appears to trigger the accumulation of glycerol in third-instar larvae; this accumulation in the larva is closely correlated with the drying of the surrounding gall tissues as the plant senesces (Rojas et al. 1986). Later in the autumn decreases in environmental temperature to 0 to $5^{\circ} \mathrm{C}$ trigger sorbitol synthesis from glycogen in the fat body cells (Baust \& Lee 1981, 1982, Storey et al. 1981).

It is generally believed that freeze tolerance under natural conditions is possible only if the ice lattice is restricted to the extracellular space (Mazur 1984). This notion is based on an extrapolation from the cryopreservation of mammalian cells that would never naturally experience subzero temperatures. Surprisingly this premise has rarely been investigated directly in cells from naturally freeze-tolerant organisms. However, on 2 occasions Salt $(1959,1962)$ reported intracellular freeze tolerance in the fat body cells of Eurosta solidaginis. For more than 30 yr Salt's observations on this novel phenomenon were largely ignored.

Salt's observations were recently confirmed and extended by examining freezing injury and cryoprotection using cryomicroscopy and fluorescent vital dyes (Lee et al. 1993). Although intact larvae of Eurosta sol-

Table 1. Eurosta solidaginis. Summary of supercooling points and lower limit of freeze tolerance in overwintering larvae of the goldenrod gall fly from different geographic locations in North Amenca

\begin{tabular}{|lccl|}
\hline Location & $\begin{array}{c}\text { Supercooling } \\
\text { point }\left({ }^{\circ} \mathrm{C}\right)\end{array}$ & $\begin{array}{c}\text { Lower limit of } \\
\text { freeze tolerance }\left({ }^{\circ} \mathrm{C}\right)\end{array}$ & Source \\
\hline Houston. Texas & -8 to -14 & $<-25$ & Baust \& Lee (1981, 1982) \\
Oxford, Ohio & -8 to -10 & -40 & J. A. Mugnano (unpubl.) \\
Candor, New York & -8 to -9 & -55 & Bale et al. (1989a, b) \\
St. Paul, Minnesota & -7 to -10 & $<-25$ & Baust \& Lee (1981, 1982) \\
Lethbridge, Alberta & - & -55 & Salt (1957) \\
\hline
\end{tabular}


idaginis did not survive freezing to $-80^{\circ} \mathrm{C}$, a substantial proportion of the fat body cells did. This result suggests that the fat body is not the most labile tissue in the larvae and that some other site, possibly the nervous system, is most susceptible to freezing injury and thus determines the lower lethal temperature for larval survival. The addition of glycerol to a cell suspension allowed fat body cells to survive to lower temperatures than in its absence. These results are significant for 2 reasons. They directly challenge the cryobiological dogma from the study of mammalian cells and tissues, particularly those of humans, that survival is possible only if ice formation is restricted to the extracellular space. Tolerance of intracellular freezing might be common in organisms that have evolved mechanisms to survive freezing. Secondly, the future use of vital dyes and other metabolic measures of cell survival should allow more direct observations of the nature of chilling and freezing injury and cryoprotection in insects.

\section{OVERWINTERING BIOENERGETICS}

In temperate regions insects usually overwinter in diapause, a dormant state of depressed metabolic activity and increased resistance to environmental extremes (Tauber et al. 1986, Danks 1987). Generally insects enter diapause before the onset of adverse environmental conditions. Since food is unavailable during winter, energy reserves in the form of lipid and glycogen are accumulated in preparation for winter. Not only are these reserves essential as an energy source for overwintering survival, but frequently they provide the primary energy reserve for reproduction in the spring and summer. Consequently, controlled use of these reserves is critical.

Although numerous studies have investigated the cold-hardiness of Eurosta solidaginis, little is known about the overwintering bioenergetics of this species. Consequently, we investigated seasonal changes in total body lipids and energy content in relation to environmental temperature during the winter. Total lipids were determined gravimetrically following the methods of Pullin (1987) and Christie (1982). Caloric content was determined on larvae dried to a constant weight at $50^{\circ} \mathrm{C}$ prior to combustion in a Phillipson microbomb calorimeter (Phillipson 1964).

In the interval from October to February the highest maximum temperatures in Oxford, Ohio, were greater than $20^{\circ} \mathrm{C}$ in
October through the third week in November; thereafter, maximum temperatures began to decline and generally remained between 8 and $15^{\circ} \mathrm{C}$ for the remainder of the winter (Fig, 1). In October the average weekly temperature was approximately $8^{\circ} \mathrm{C}$ compared to $5.5^{\circ} \mathrm{C}$ in November. During an exceptionally cold period in December and January average temperatures remained below $0^{\circ} \mathrm{C}$, with the coldest week having a mean value of $-9.6^{\circ} \mathrm{C}$. The lowest temperature recorded during this study was $-22.1^{\circ} \mathrm{C}$. The range of maximum to minimum weekly temperatures was commonly 20 or 25 degrees, and as great as 34.8 degrees within 1 wk. Layne (1991) reported similar thermal extremes within galls in western New York.

During the interval from October to March larval weight decreased by $34 \%$ (Fig. 2). The greatest loss $(16.7 \%)$ occurred in October and November when ambient temperatures were highest. In contrast, larval water content ( 59 to $63 \%$ ) remained relatively constant during the winter. Total mean lipid content decreased from October (10.2 $\mathrm{mg}$ ind..$^{-1}$ ) to $\operatorname{March}\left(7.4 \mathrm{mg}\right.$ ind. ${ }^{-1}$ ), a $27.5 \%$ loss (Fig. 2). As occurred for body weight, the greatest proportion of this loss $(22.5 \%)$ took place between October and December. A similar pattern was evident for the total caloric content, which decreased markedly during October. A Texas population of Eurosta solidaginis showed a similar decrease in larval weight of approximately $40 \%$ from November to January, with water content remaining constant in the range of 60 to $64 \%$ (Rojas et al. 1986). In contrast, Storey \& Storey (1986) reported relatively constant larval weight and lipid levels during the winter for a population near Ottawa, Ontario, Canada. This difference

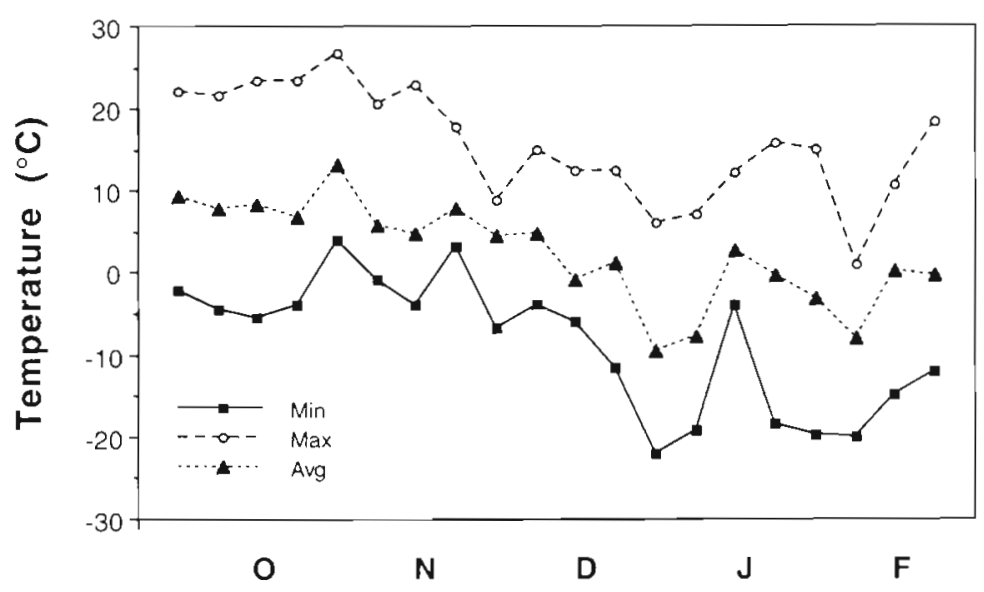

Fig. 1. Weekly maximum and minimum temperature, and average weekly temperatures, recorded at Miami University Ecology Research Center, Oxford, Ohio, USA, from October 1987 through February 1988. Temperatures were taken at $1.5 \mathrm{~m}$ above the ground, which corresponds closely with the average height $(1.2 \mathrm{~m})$ of the goldenrod galls from which the Eurosta solidaginis larva were collected 

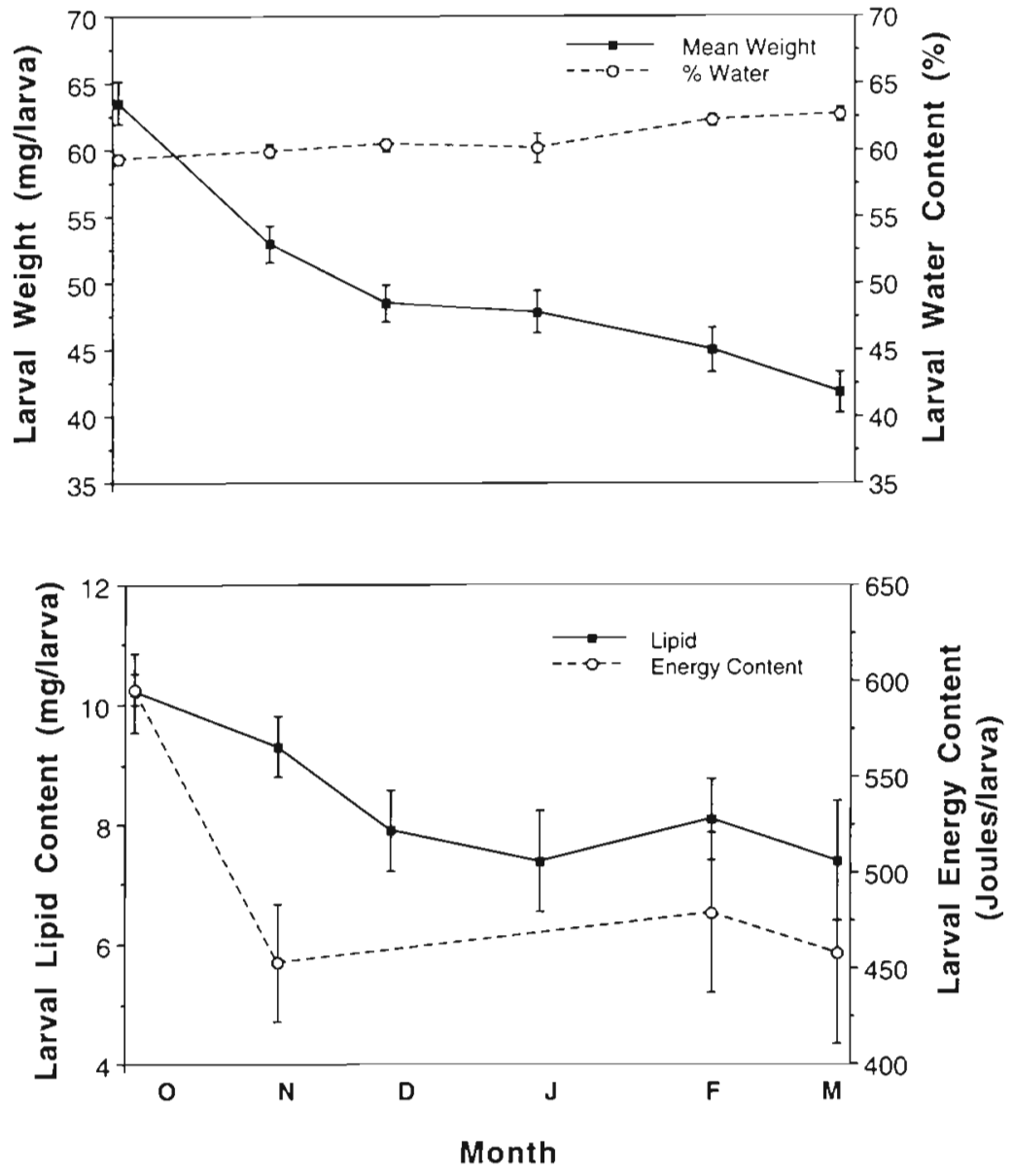

Fig. 2. Eurosta solidaginis. Seasonal changes in mean larval live weight and water content expressed as percentage of live weight (mean $\pm S E M, n=32$ ) (top panel), and mean total lipid content and mean energy content per larva (mean \pm SEM, $n=5$ or 6 ) (bottom panel) in overwintering larvae and its termination with phenological changes in the environment. Development of overwintering Eurosta solidaginis is arrested in the larval stage. Many insects rely on increasing temperatures in late winter or spring for the resumption of development (Tauber et al. 1986 , Danks 1987). From an evolutionary perspective the gall fly larva's developmental decision centers on whether a period of warming represents a temporary period of milder conditions that will be followed by low or even subzero temperatures, or the arrival of spring with conditions suitable for a resumption of development and metamorphosis to the pupal stage. Premature continuation of development is potentially lethal since it is accompanied by loss of freeze tolerance (Morrissey \& Baust 1976).

We tested response of larvae to warming by acclimating them to $15^{\circ} \mathrm{C}$ for $5 \mathrm{~d}$ in the laboratory. Oxygen consumption was measured in 1 cc syringes fitted with 20 ul micropipettes as described by Lee \& Baust (1982). This experiment was first done in January and repeated in March. In both months the initial oxygen consumption rates at $15^{\circ} \mathrm{C}$ were approximately $123 \mathrm{nl} \mathrm{mg}^{-1}$ $\mathrm{h}^{-1}$. During the first $3 \mathrm{~d}$ of acclimation, consumption rates remained near or below the initial value (Fig. 4). How- may, in part, be explained by the fact that environmental temperatures are lower in Ontario than in Ohio and Texas. Lower environmental temperatures would slow the metabolic rate of larvae, thus reducing the rate of lipid use and weight loss.

The metabolic rate of actively feeding and reproducing insects is characteristically much higher than that of diapausing stages. The rate of oxygen consumption in overwintering Eurosta solidaginis larvae was strongly influenced by temperature $\left(y=-66+14.2 x, \mathrm{r}^{2}\right.$ $=0.98$; Fig. 3). Oxygen consumption increased 6 -fold between $5^{\circ} \mathrm{C}$ and $10^{\circ} \mathrm{C}$ in December larvae. Consequently, the effect of the relatively high environmental temperatures in October and early November on the metabolic rate most likely accounts for the significant decreases observed in body weight, lipid and caloric content.

An important problem faced by overwintering insects is how to synchronize both entry into diapause

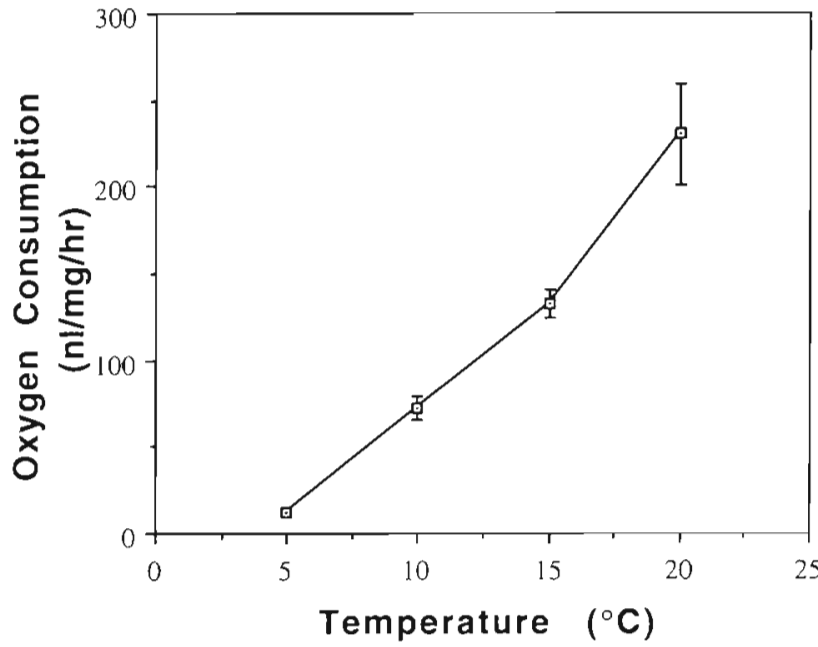

Fig. 3. Eurosta solidaginis. Effect of temperature on oxygen consumption of overwintering larvae collected in December 1987 (mean \pm SEM, $\mathrm{n}=5$ to 8 ) 


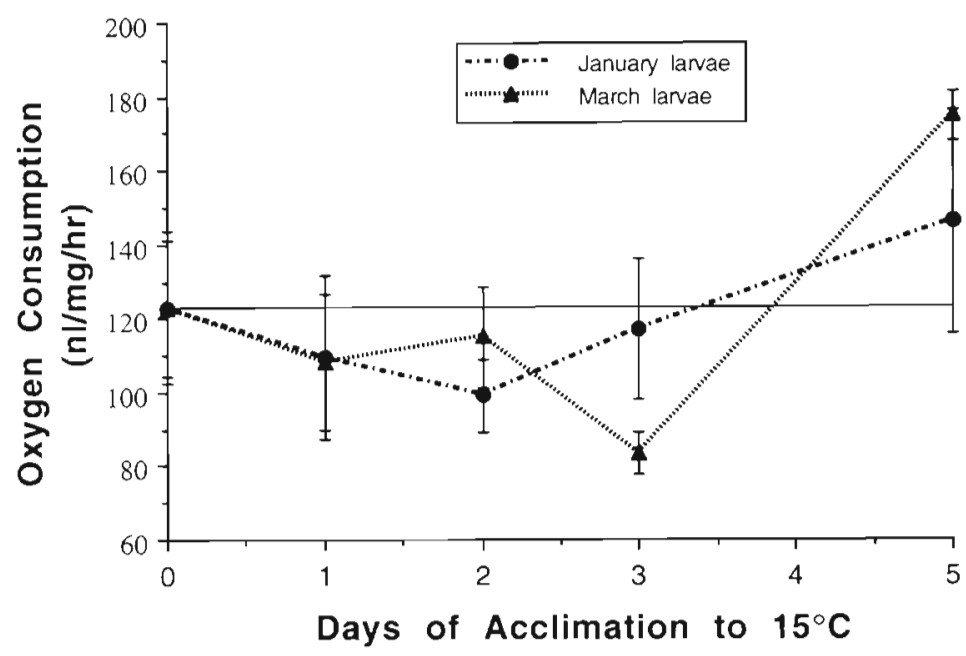

Fig. 4. Eurosta solidaginis. Oxygen consumption of overwintering larvae at $15^{\circ} \mathrm{C}$ following acclimation to $15^{\circ} \mathrm{C}$ for up to $5 \mathrm{~d}$ (mean $\pm \mathrm{SEM}, \mathrm{n}=5$ to 8 ). The horizontal line indicates the rate of oxygen consumption at the beginning of the experiment

ever, by the fifth day oxygen consumption rates markedly increased, suggesting a transition from a physiological state of energy conservation in winter to one of elevated metabolism that is required for resumption of development and preparation for metamorphosis. The $3 \mathrm{~d}$ lag in the elevation of the respiration rate may represent a safeguard against premature exit from the overwintering state.

\section{INVOLVEMENT OF HEAT SHOCK (STRESS) PROTEINS}

One of the universal responses by organisms to high temperature is the synthesis of heat shock proteins. While it has been known for some time that certain other forms of stress can also elicit the synthesis of these proteins (and hence the name stress proteins is perhaps more appropriate), it has been found only recently that low temperature can also stimulate synthesis of these proteins. Low-temperature stimulation of heat shock protein synthesis has now been documented for the fruit fly Drosophila melanogaster (Burton et al. 1988), the flesh fly Sarcophaga crassipalpis (Joplin et al. 1990), and the gypsy moth Lymantria dispar (Yocum et al. 1991, Denlinger et al. 1992). Although the function of these proteins at low temperature is not at all clear (Denlinger et al. 1991), their presence and persistence at low temperature certainly suggest that they may contribute to low-temperature tolerance.

We tested whether Eurosta solidaginis also synthesizes heat shock proteins in response to low temperature. The other 3 insect species previously examined for heat shock protein synthesis at low temperature cannot tolerate body freezing and all die at temperatures well above their supercooling points. Thus, it was not at all clear whether $E$. solidaginis, a freezetolerant species, would respond in the same way.

To test for a possible contribution of heat shock proteins in the low-temperature response of Eurosta solidaginis, galls containing third-instar larvae were collected in central Ohio in mid-autumn (October 1991) and in winter (mid-November 1991 to January 1992). Larvae in October have not yet become freeze tolerant, but the drop in temperature by early winter stimulates cryoprotectant synthesis and causes the larvae to become freeze tolerant (Baust \& Lee 1982). Thus, our samples represented both younger freeze-intolerant and older freezetolerant individuals.

First, we documented the high-temperature response by exposing intact larvae collected in October to various high temperatures for $1 \mathrm{~h}$, dissecting and culturing the larval brains as a sample organ, pulselabeling the brains with ${ }^{35} \mathrm{~S}$-methionine for $1 \mathrm{~h}$, extracting and separating the proteins by polyacrylamide gel electrophoresis, and detecting the proteins with autoradiography as previously described (Joplin \& Denlinger 1990). As expected, at high temperatures normal protein synthesis was shut down, but a select group of proteins, the heat shock proteins, was synthesized (Fig, 5A). Proteins with molecular weights of 94 and $71 \mathrm{kDa}$ were the 2 primary heat shock proteins produced, and maximal expression occurred around $35^{\circ} \mathrm{C}$.

To search for the expression of heat shock proteins in response to low temperature, October larvae were exposed for $2 \mathrm{~h}$ to a range of low temperatures from -5 to $-20^{\circ} \mathrm{C}$ i brains were labeled for $1 \mathrm{~h}$ either immediately after the low-temperature exposure (Fig. 5B, left lanes) or after a $2 \mathrm{~h}$ period of recovery at $25^{\circ} \mathrm{C}$ (Fig. 5B, right lanes). The experimental temperatures used were both above and below the supercooling point $\left(-12^{\circ} \mathrm{C}\right)$ recorded in larvae at that time of year (Baust \& Nishino 1991). There was no evidence that synthesis of heat shock proteins was stimulated by any of the low temperatures tested. The same response was observed in winter larvae that had already become freeze tolerant. Again, we found no evidence that low temperatures above or below the supercooling point could stimulate synthesis of heat shock proteins (data not shown).

Thus, unlike other insects tested previously, Eurosta solidaginis does not appear to synthesize heat shock 
A

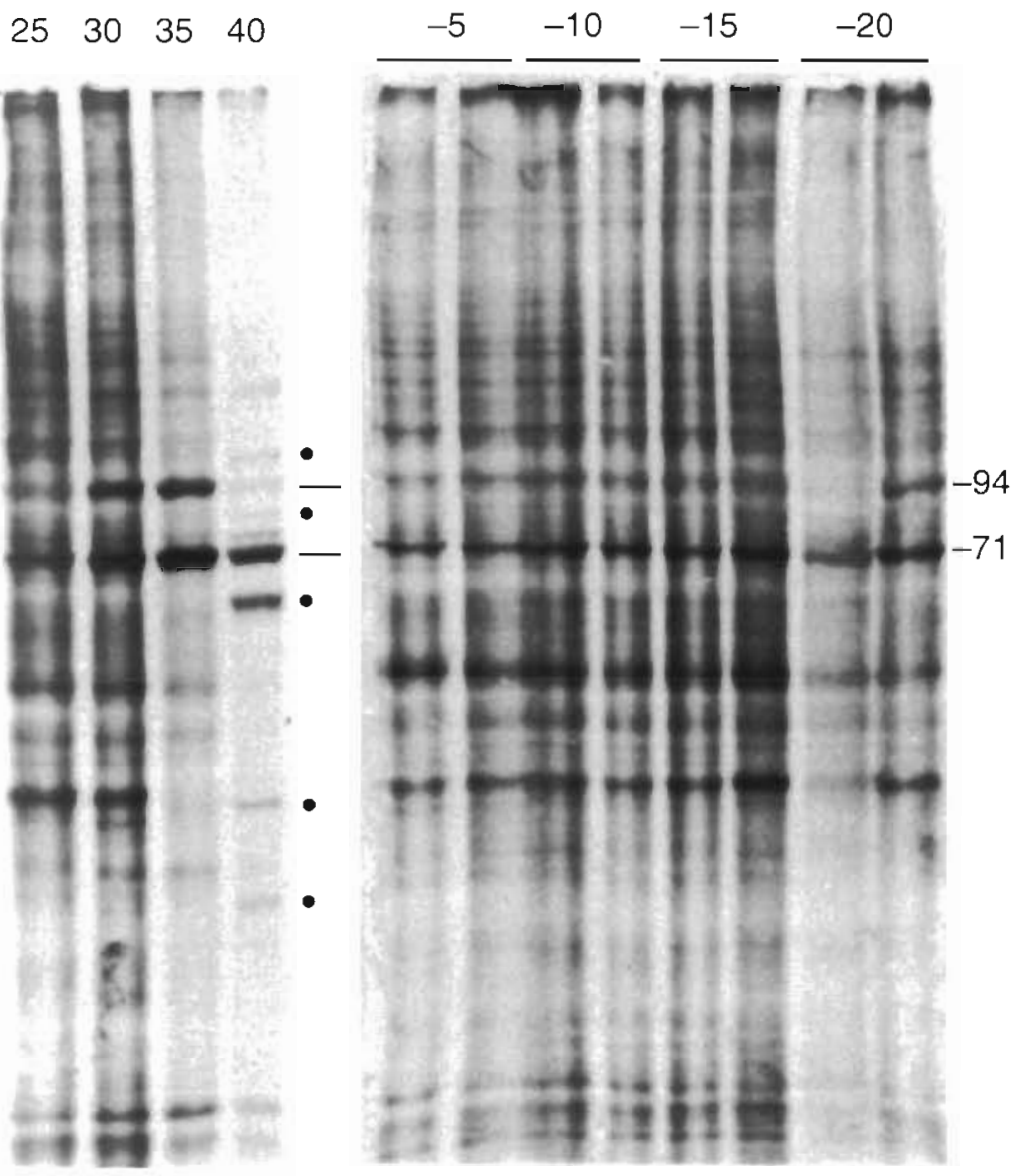

B
Fig. 5. Eurosta solidaginis. Autoradiogram of SDS-PAGE gel showing the pattern of protein synthesis in heat shocked and cold treated third-instar larvae Brains were pulse-labeled in vitro for $1 \mathrm{~h}$ after treatment. (A) Five brains were treated at each temperature (designated at the top of the column) for $1 \mathrm{~h}$ and then labeled with $10 \mu \mathrm{Ci} \mu l^{-1}$ Trans $^{35} \mathrm{~S}$-label ${ }^{\mathrm{TM}}$ for an additional hour. The molecular weights of the 2 major heat shock proteins are indicated in $\mathrm{kDa}$. Dots indicate additional proteins seen at $40^{\circ} \mathrm{C}$. (B) Proteins from the same tissues produced after cold treatment. Five larvae were treated at each temperature, the brains dissected and then pulse-labeled either immediately (left lanes) or after $2 \mathrm{~h}$ (right lanes) for $1 \mathrm{~h}$ at $25^{\circ} \mathrm{C}$ proteins in response to low temperature. Perhaps this difference represents a general trend distinguishing freeze-tolerant and freeze-intolerant species, but many more species will need to be examined before such a generalization can be validated.

Acknowledgements. We gratefully acknowledge support by NSF grant \#[BN-9305809.

\section{LITERATURE CITED}

Abrahamson WG, Sattler JF, MCCrea KD, Weis AE (1989) Variation in selection pressures on the goldenrod gall fly and the competitive interactions of its natural enemies. Oecologia 79:15-22

Bale JS, Hansen TN, Baust JG (1989a) Nucleators and sites of nucleation in the freeze tolerant larvae of the gallfly Eurosta solidaginis (Fitch). J Insect Physiol 35:291-298

Bale JS, Hansen TN, Nishino M, Baust JG (1989b) Effect of cooling rate on the survival of larvae, pupariation, and adult emergence of the gallfly Eurosta solidaginis. Cryobiology 26:285-289

Baust JG, Grandee R, Condon G. Mornssey RE (1979) The diversity of overwintering strategies utilized by separate populations of gall insects. Physiol Zool 52:572-580

Baust JG, Lee RE (1981) Divergent mechanisms of frosthardiness in two populations of the gall fly, Eurosta solidaginis. J Insect Physiol 27:485-490

Baust JG, Lee RE (1.982) Environmental triggers to cryoprotectant modulation in separate populations of the gall fly, Eurosta solidaginis (Fitch). J Insect Physiol 28:431-436

Baust JG, Nishino M (1991) Freezing tolerance in the goldenrod gall fly Eurosta solidaginis. In: Lee RE, Denlinger DL (eds) Insects at low temperature. Chapman and Hall, New York, p 260-275

Burton V, Mitchell HK, Young P. Peterson NS (1988) Heat shock protection against cold stress of Drosophila melanogaster. Molec cell Biol 8:3550-3552

Cane JH, Kurczewski FE (1976) Mortality factors affecting Eurosta solidaginis (Diptera: Tephritidae). J NY Entomol Soc $84: 275-282$

Christie WW (1982) Lipid analysis, 2nd edn. Pergamon Press, Oxford

Danks HV (1987) Insect dormancy: an ecological perspective. Biological Survey of Canada (Terrestrial Arthropods), Ottawa

Denlinger DL, Joplin KH, Chen CP, Lee RE (1991) Cold shock and heat shock. In: Lee RE, Denlinger DL (eds) Insects at low temperature. Chapman and Hall, New York. p $131-148$ 
Denlinger DL, Lee RE, Yocum GD, Kukal O (1992) Role of chilling in the acquisition of cold tolerance and the capacitation to express stress proteins in diapausing pharate larvae of the gypsy moth, Lymantria dispar. Arch Insect Biochem Physiol 21:271-280

Joplin KH, Denlinger DL (1990) Developmental and tissue specific control of the heat shock induced $70 \mathrm{kDa}$ related proteins in the flesh fly, Sarcophaga crassipalpis. J Insect Physiol 36:239-249

Joplin KH, Yocum GD, Denlinger DL (1990) Cold shock elicits expression of heat shock proteins in the flesh fly, Sarcophaga crassipalpis. J Insect Physiol 36:825-834

Layne JR (1991) Microclimate variability and the eurythermic nature of goldenrod gall fly (Eurosta solidaginis) larvae (Diptera: Tephritidae). Cán J Zool 69:614-617

Layne JR, Lee RE, Huang JL (1990) Inoculation triggers freezing at high subzero temperatures in a freeze-tolerant frog (Rana sylvatica) and insect (Eurosta solidaginis). Can $J$ Zool 68:506-510

Lee RE, Baust JG (1982) Respiratory metabolism of the Antarctic tick, Ixodes uniae. Comp Biochem Physiol 72A: $167-171$

Lee RE, Lewis EA (1985) Effect of temperature and duration of exposure on tissue ice formation in the gall fly, Eurosta solidaginis (Diptera, Tephritidae). Cryo-Lett 6: $25-34$

Lee RE, McGrath JG, Morason RT, Taddeo RM (1993) Survival of intracellular freezing, lipid coalescence and osmotic fragility in fat body cells of the freezetolerant gall fly Eurosta solidaginis. J Insect Physiol 39: $445-450$

Lee RE, Mugnano JA, Taylor RT (1992) Endogenous crystalloid spheres regulate the supercooling point of the gall fly, Eurosta solidaginis. Cryobiology 29: $750-751$

Mazur P (1984) Freezing of living cells: mechanisms and implications. Am J Physiol (Cell Physiol) 16:C125-C142

Miller WE (1959) Natural history notes on the goldenrod ball gall fly, Eurosta solidaginis (Fitch), and on its parasites, Eurytoma obtusiventris Gahan and E. gigantea Walsh. J Tenn Acad Sci 34:246-251

Morrissey RE, Baust JG (1976) The ontogeny of cold tolerance in the gall fly, Eurosta solidaginis. J Insect Physiol 22: $431-437$
Phillipson J (1964) A miniature bomb calorimeter for small biological samples. Oikos 15:130-139

Pullin AS (1987) Adult feeding time, lipid accumulation, and overwintering in Aglais urticae and Inachis io (Lepidoptera: Nymphalidae). J Zool Lond 211:631-641

Rojas RR, Lee RE, Baust JG (1986) Relationship of environmental water content to glycerol accumulation in the freezing tolerant larvae of Eurosta solidaginis (Fitch). Cryo-Lett. 7:234-245

Salt RW (1957) Natural occurrence of glycerol in insects and its relation to their ability to survive freezing. Can Entomol 89:491-494

Salt RW (1959) Survival of frozen fat body cells in an insect. Nature 184:1426

Salt RW (1962) Intracellular freezing in insects. Nature 193: $1207-1208$

Storey KB, Baust JG, Storey JM (1981) Intermediary metabolism during low temperature acclimation in the overwintering gall fly larvae, Eurosta solidaginis. J comp Physiol 14:183-190

Storey KB, Storey JM (1986) Winter survival of the gall fly larvae, Eurosta solidaginis: profiles of fuel reserves and cryoprotectants in a natural population. J Insect Physiol 32:549-556

Storey KB, Storey JM (1988) Freeze tolerance in animals. Physiol Rev 68:27-84

Tauber M, Tauber C, Masaki S (1986) Seasonal adaptations of insects. Oxford University Press, New York

Uhler LD (1951) Biology and ecology of the goldenrod gall fly, Eurosta solidaginis (Fitch). Cornell Univ Agric Exp Stat Mem 300:1-51

Uhler LD (1961) Mortality of the goldenrod gall fly, Eurosta solidaginis in the vicinity of Ithaca, New York. Ecology 42:215-216

Waring GL, Abrahamson WG, Howard DJ (1990) Genetic differences among host-associated populations of the gallmaker Eurosta solidaginis (Diptera: Tephritidae). Evolution 44:1648-1655

Yocum GD, Joplin KH, Denlinger DL (1991) Expression of heat shock proteins in response to high and low temperature extremes in diapausing pharate larvae of the gypsy moth Lymantria dispar. Arch Insect Biochem Physiol 18: $239-249$ 